$1-1-1928$

\title{
Effect of Winter Rations on Pasture Gains of Calves Marketed as Three-Year-Old Steers
}

\author{
C. V.Wilson \\ E.W. Sheets \\ R.H. Tuckwiller
}

Follow this and additional works at: https://researchrepository.wvu.edu/ wv_agricultural_and_forestry_experiment_station_bulletins

\section{Digital Commons Citation}

Wilson, C. V.; Sheets, E. W.; and Tuckwiller, R. H., "Effect of Winter Rations on Pasture Gains of Calves Marketed as Three-Year-Old Steers" (1928). West Virginia Agricultural and Forestry Experiment Station Bulletins. 218.

https://researchrepository.wvu.edu/wv_agricultural_and_forestry_experiment_station_bulletins/218 @ WVU. It has been accepted for inclusion in West Virginia Agricultural and Forestry Experiment Station Bulletins by an authorized administrator of The Research Repository @ WVU. For more information, please contact ian.harmon@mail.wvu.edu. 
West Virginia University Libraries 
EVASSDALE LIBRARY WEST VIRGINA UNVERSTIY 
Restricted

\section{Circulation Only}

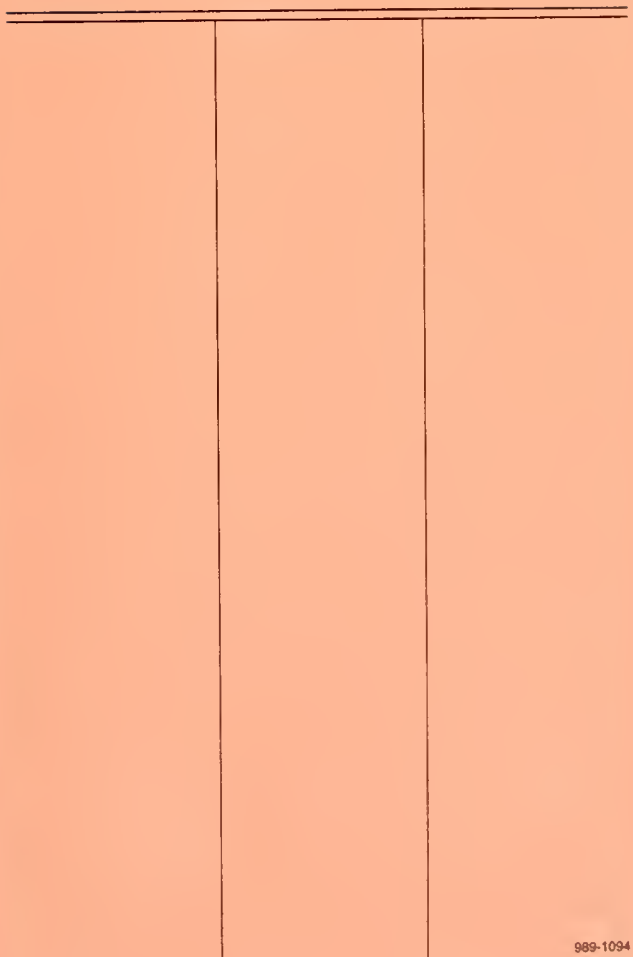





\title{
Aqrícultural Experiment Station
}

College of Agriculture, Jalest Zirginia Anibersity

\author{
N. J. GIDDINGS, Acting Director \\ Morgantown
}

\section{iffect of Winter Rations on Pasture Gains of Calves OrCarketed as Three-Year-Old Steers}

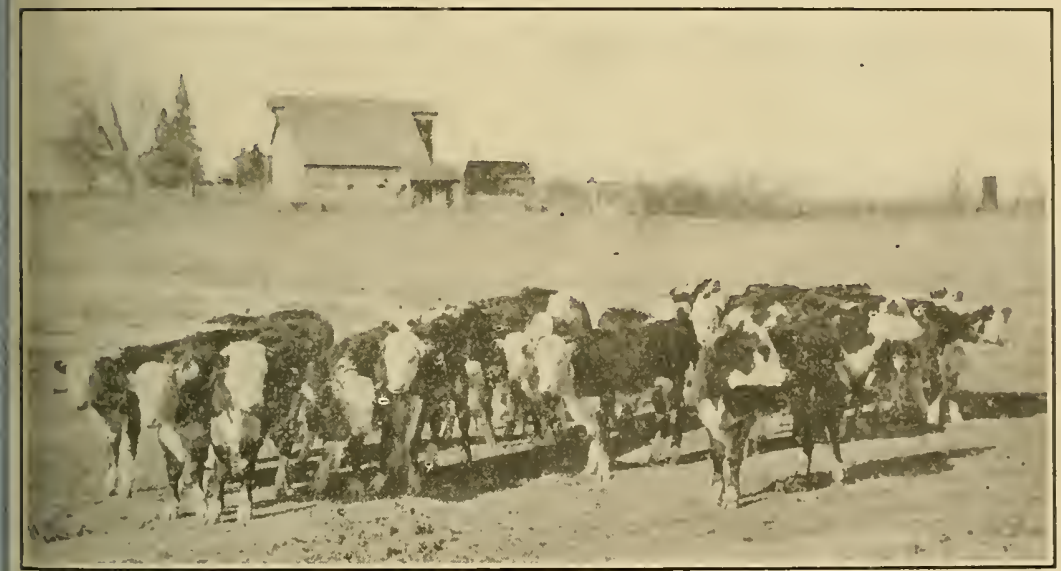

Fig. 2.-Calves at Beginning of Experiment, December 22, 1922.

By

C. V. WILSON, R. H. TUCKWILLER, and

E. W. SHEETS

Publications of this Station will be mailed free to any citizen of West Virginia upon ritten application. Address Director of the West Virginia Agricultural Experiment Staon, Morgantown, West Virginia. 


\section{AGRICULTURAL EXPERIMENT STATION STAFF}

FRANK BUTLER TROTTER, A. M., LL. D............ President of the Unive

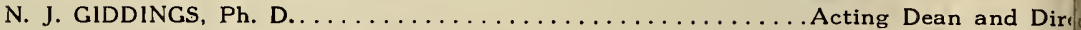

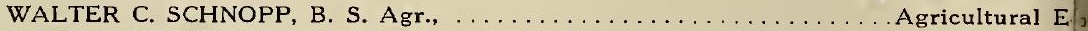

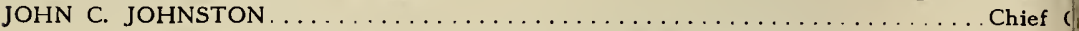

\section{AGRONOMY AND GENETICS}

R. J. Garber. Ph. D. Agronomist and Ceneticist

E. P. Deatrick, Ph. D. Associate Agronomist (Solls)

T. E. Odland, Ph. D. Associate Agronomist

T. C. Mcllvaine, Ph. D. $\dagger$ Assistant Agronomist (Soils)

D. R. Dodd, M. S. Assistant Agronomist

M. M. Hoover, M. S. Junior Agronomist

H. K. Rowley, M. S. Agr.**

Seed Analyst

ANIMAL HUSBANDRY

E. A. Livesay, M. S

Animal Husbandman

Chas. V. Wilson, M. S.

Assistant Animal Husbandman

J. H. Longwell, M. A.,

Assistant Animal Husbandman

J. H. Rietz, D. V. M.

Associate Veterinarian

R. H. Tuckwiller, B. S. Agr.* Assistant Animal Husbandman

\section{CHEMISTRY}

R. B. Dustman, Ph. D.

Associate Chemist

Chas. E. Weakley, Jr., B. A.

Assistant Chemisi

L. P. Hansen, Ph. D.

Assistant Chemist

T. B. Leith, B. A.**

Assistant Chemist

Leland Shriver

$$
\text { Assistant in Chemistry }
$$

DAIRY HUSBANDRY

E. L. Anthony, M. S. Agr.

$$
\text { Dairy Husbandman }
$$

H. O. Henderson, M. S. Agr. Associate Dairy Husbandman

G. Malcolm Trout, M. S. Assistant Dairy Husbandman ENTOMOLOGY

L. M. Peairs, Ph. D.

W. E. Rumsey, B. S.** State Entomologist

L. E. Dills, M. S.**

Assistant in Entomology

\section{FARM ECONOMICS}

A. J. Dadisman, Ph. D. Farm Econc

Paul A. Eke, Ph. D.

Assistant Farm Econc

F. D. Cornell, Jr., M. S.

Junior Farm Mechan

W. W. Armentrout, M. S. Junior Farm Econd

\section{HOME ECONOMICS}

Rachel H. Colwell, A. M.

Home Econcis

Hazel C. Cameron, M. S.

Research Specialist in $F d$

Nell Nesbitt, A. M.

Research Specialist in Home

HORTICULTURE

H. E. Knowlton, $\mathrm{Ph}, \mathrm{D}$.

Associate Horticult is

H. L. Crane, M. S. Agr. Associate Horticult

K. C. Westover, M. S. Agr. Assistant Horticultis

L. F. Sutton, B. S. Agr. $\ddagger$ Assistant Horticuit is

H. P. Sevy, M. S. Agr. Assistant in Horticuir!

M. B. Hoffman, M. S. Assistant in Horticuin

\section{PLANT PATHOLOGY}

N. J. Giddings, Ph. D. Plant Patholis

Anthony Berg, M. S. Associate Plant Patho! is

L. H. Leonian, Ph. D. Associate Plant Pathol i

E. C. Sherwood, M. S. Assistant Plant Pathol is

\section{POULTRY HUSBANDRY}

Horace Atwood, M. S. Agr. Poultry Husban ai

E. T. Wightman, M. S. Agr. Junior Poultry Husban ar

RURAL SOCIOLOGY

T. L. Harris, Ph. D.

Rural Socio is

ZOOLOGY

F. E. Chidester, Ph. D.

*In cooperation with the U. S. Department of Agriculture, Washington, D. C. tln charge of the Lakin Sub-Station, Lakin, W. Va.

**In cooperation with the State Department of Agriculture, Charleston, W. Vo

$\ddagger$ ln charge of the Reymann Memorial Farms, Wardensville, W. Va 
general, although there are many sections where the practice is 1 lowed, particularly in the valleys of some of the larger streams. far the greater number of farmers who handle beef cattle either gr stockers and feeders or finish cattle for market from grass alo Therefore, one of the principal beef-production problems is to det mine the best and most economical method of wintering the ca and the one that will enable them to make the best possible use the pasture the following summer, when the cheapest gains are ma A common practice in this area has been to winter steers on dry fe such as hay, corn stover, and wheat straw, and on corn silage $t$ less extent, in such way that they lose materially in weight. $T$. are then pastured the following summer and sold from grass stockers, feeders, or finished steers. There are some who hold t it is profitable to permit this loss of weight, which with older ste's usually varies from 25 to 100 pounds. Others believe that ca wintered on silage, or on a ration of which silage is a part, will not. well on grass the following summer.

\section{OBJECTS AND PLAN OF THE WORK}

The experiments as a whole had the following general probl in view:

(1) To ascertain the effect of different wintering rations in subsequent pasture gains.

(2) To determine the most satisfactory and economical met of wintering.

(3) To determine the best method and the cost of raising I cattle in West Virginia.

The results of previous work with cows, calves, yearlings, two-year-olds are published in bulletins 186,190, and 191 of the V Virginia Agricultural Experiment Station and in United States Dep ment of Agriculture bulletins 870, 1024, 1042, and 1251, res tively. In all the previous work the cattle were kept one year 0

This bulletin is a report of the work with calves kept from w ing age until marketed as three-year-old steers.

The objects of this experiment were:

(1) To study the effects of the following winter rations w fed to calves, upon the subsequent gains of the steers on pasture when marketed as grass-fat three-year-olds.

\begin{tabular}{lll} 
RATION I & \multicolumn{1}{c}{ RATION II } & \multicolumn{1}{c}{ RATION III } \\
Clover hay & Cottonseed meal & Mixed hay \\
Corn silage & Corn silage & Grain mixture \\
Wheat straw & Wheat straw &
\end{tabular}


(2) To study the effects of the following rations when fed to same calves as yearlings, upon the subsequent gains of the steers il marketed as grass-fat three-year-olds.

RATION I

Clover hay

Corn silage

Wheat straw
RATION II

Cottonseed meal

Corn silage

Wheat straw
RATION III

Mixed hay

Corn silage

Wheat straw

The three lots of yearlings fed during the winter of 1923-24 e each made up of 30 steers, 10 from each of the three lots of the ceding year.

(3) To obtain a continuous feed and growth record for steers $\mathrm{n}$ weaning age until they are fattened on grass as three-year-olds.

\section{KIND OF STEERS USED}

For use in this experiment 100 good to choice Hereford steer ires were obtained in north central Texas. They arrived at the En about the end of November, 1922, having been in transit from as 18 days and showing to a marked degree the effects of the long crney and insufficient feed. On December 22, when the feeding t'ted, the calves averaged 386 pounds in weight, ranging from 300 ci00 pounds. (See Figure 2, on cover page.)

\section{METHOD OF FEEDING AND HANDLING THE STEERS}

For the experimental feeding 90 of the calves were selected and ided into three lots of 30 each. In making this division care was en to have the lots as nearly uniform as possible in quality, size, al condition. The three lots were each given the same amount of ice in an open barn and were kept under cover all winter. The t:rs were fed twice a day, and the feed, both concentrates and (ghage, was carefully weighed at each feeding. Water was sup: $d$ in the barn at all times and salt was constantly available.

The steers were weighed individually three days in succession at beginning and at the end of the winter feeding period, and averis taken for their initial and final weights. They were also weighed e every 28 days, in the morning after feeding. Numbered ear tags e used, so that ready identification of each individual could be de and records accurately kept.

In the spring of each year, as soon as the grass was good enough, ch was usually about April 25, the steers from all the lots were led into the same or similar pastures with no additional feed. $\mathbb{X}$ ights were taken once every 28 days during the first two summers. -ing the last summer, weights were taken only once, July 22 , before final weight on September 10, when they were marketed. 
One steer was struck by lightning on June 6,1925 , this being only animal lost in the three years.

The outline in Table 1 shows how the steers were fed each win until they were fattened on grass as three-year-olds. Only the ferl to be compared are put into the diagram. Corn silage and wh straw were fed to every lot each winter, except Lot III in the $f_{3}$ winter, which received mixed hay and a grain mixture.

TABLE 1.-Outline of Three Years' Winter Feeding.

\begin{tabular}{|c|c|c|c|c|c|c|}
\hline \multicolumn{3}{|c|}{$1922-23$} & \multicolumn{2}{|c|}{$1923-24$} & \multicolumn{2}{|c|}{$1924-25$} \\
\hline & Lot & Ration & Lot & Ration & Lot & Ration \\
\hline$(30$ & $\begin{array}{l}\text { I } \\
\text { calves) }\end{array}$ & $\begin{array}{l}\text { Clover hay } \\
\text { Corn silage } \\
\text { Wheat straw }\end{array}$ & $\begin{array}{l}\text { A } \\
\text { (30 yearlings. } \\
10 \text { each from } \\
\text { Lots } 1,11 \text {, and } \\
\text { III of preced- } \\
\text { ing winter) }\end{array}$ & $\begin{array}{l}\text { Clover hay } \\
\text { Corn silage } \\
\text { Wheat straw } \\
\end{array}$ & $\begin{array}{l}\text { (90 head two- } \\
\text { year - olds, } \\
\text { Lots A, B, } \\
\text { and } C \text { of pre- } \\
\text { ceding winter } \\
\text { combined) }\end{array}$ & $\begin{array}{l}\text { Cottons } \\
\text { meal } \\
\text { Corn sil } \\
\text { Wheat st }\end{array}$ \\
\hline$(30$ & $\begin{array}{l}\text { II } \\
\text { calves) }\end{array}$ & $\begin{array}{l}\text { Cottonseed } \\
\text { meal } \\
\text { Corn silage } \\
\text { Wheat straw }\end{array}$ & $($ Same as A) & $\begin{array}{l}\text { Cottonseed } \\
\text { meal } \\
\text { Corn silage } \\
\text { Wheat straw } \\
\text { Wheal }\end{array}$ & & \\
\hline$(30$ & $\begin{array}{l}\text { III } \\
\text { calves) }\end{array}$ & $\begin{array}{l}\text { Mixed hay } \\
\text { Grain mix- } \\
\text { ture* }\end{array}$ & (Same as A) & $\begin{array}{l}\text { Mixed hay } \\
\text { Corn silage } \\
\text { Wheat straw }\end{array}$ & & \\
\hline
\end{tabular}

*Consisted of 3 parts, by weight, of corn, 1 of bran, and 1 of linseed meal.

\section{QUANTITY OF FEED CONSUMED AND GAINS MADE}

Table 2 shows the total quantity of the different feeds consur by the various lots and the average daily ration per steer in each during each of the three winters. All lots were fed to gain in weih during the winter.

At the beginning of the second winter feeding period, Decene 17, 1923, three new lots were made by taking 10 steers from ec of the three original lots, and these are hereafter designated as I, $A, B$, and $C$. The purpose was to offset the effects of the ratin fed the first winter and to make it possible to get a fair and di comparison of rations fed the second winter. In order to study $\mathrm{m} r$ in detail the effects of the winter ration on subsequent gains the sec winter and thereafter, each 10 steers from the original Lots I, II, III of the first winter were numbered $A_{1}, A_{2}, A_{3}, B_{1}, B_{2}, B_{3}$, and $\mathrm{C}_{2}, \mathrm{C}_{3}$. The letters designate each lot of 10 steers, and the numeal 
TABLE 2.-Average Total and Daily Rations and Gains per Steer During the Three Winters. All Amounts Are Given in Pounds.

\begin{tabular}{|c|c|c|c|c|c|c|c|}
\hline 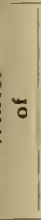 & Lot & Winter Feed & 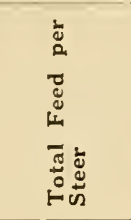 & 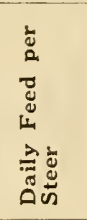 & 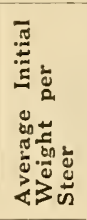 & 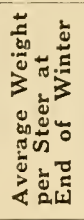 & 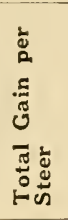 \\
\hline 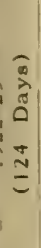 & $\begin{array}{r}11 \\
111\end{array}$ & $\left\{\begin{array}{l}\text { Clover hay } \\
\text { Corn silage } \\
\text { Wheat straw } \\
\text { Cottonseed meal } \\
\text { Corn silage } \ldots \\
\text { Wheat straw } \\
\text { Mixed hay } \\
\text { Grain mixture }\end{array}\right.$ & $\begin{array}{r}400.0 \\
1,528.5 \\
124.0 \\
92.2 \\
1,528.5 \\
412.5 \\
1,240.0 \\
368.5\end{array}$ & $\begin{array}{r}3.2 \\
12.3 \\
1.0 \\
12.7 \\
12.3 \\
3.3 \\
10.0 \\
3.0\end{array}$ & $\left\{\begin{array}{l}388 \\
383 \\
389\end{array}\right.$ & $\begin{array}{l}446 \\
462 \\
502\end{array}$ & $\begin{array}{r}58 \\
79 \\
113\end{array}$ \\
\hline 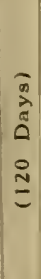 & B & $\left\{\begin{array}{l}\text { Clover hay } \ldots \\
\text { Corn silage } \\
\text { Wheat straw } \\
\text { Cottonseed meal } \\
\text { Corn silage } \\
\text { Wheat straw } \\
\text { Mixed hay } \\
\text { Corn silage } \\
\text { Wheat straw }\end{array}\right.$ & $\begin{array}{r}603.0 \\
2,166.0 \\
242.0 \\
120.0 \\
2,166.0 \\
603.0 \\
603.0 \\
2,166.0 \\
242.0\end{array}$ & $\begin{array}{r}5.0 \\
18.0 \\
2.0 \\
1.0 \\
18.0 \\
5.0 \\
5.0 \\
18.0 \\
2.0\end{array}$ & $\left\{\begin{array}{l}575 \\
576 \\
575\end{array}\right.$ & $\begin{array}{l}662 \\
655 \\
615\end{array}$ & $\begin{array}{l}87 \\
79\end{array}$ \\
\hline 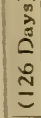 & $\begin{array}{l}\text { All three } \\
\text { lots the } \\
\text { same }\end{array}$ & $\left\{\begin{array}{l}\text { Cottonseed meal } \\
\text { Corn silage } \\
\text { Wheat straw }\end{array}\right.$ & $\begin{array}{r}135.2 \\
3,272.0 \\
607.5\end{array}$ & $\begin{array}{r}1.1 \\
26.0 \\
4.8\end{array}$ & 905 & 940 & 35 \\
\hline
\end{tabular}

*Consisted of 3 parts, by weight, of corn, 1 of bran, and 1 of linseed meal.

Idicate the source from which they came. For example, the numeral identifies the 10 head taken from the original Lot 1 . By referring , Table 2 it may be seen that Lot $\mathrm{A}$ was fed clover hay, corn silage, ind wheat straw during the winter of 1923-24 (second winter), and ach lat Lot I also received the same feeds the first winter. $A_{1}$, then, entifies 10 head of steers fed the first winter on clover hay, corn lage, and wheat straw, and the second winter on the same ration. $\mathrm{cem} / 3$ designates the 10 head fed during the winter of 1923-24 on mixed meary, silage, and wheat straw, and the previous winter on mixed hay as hid grain mixture, and so on. The gains made by the steers on pasratib re during the summer periods are shown in Table 3.

Reference to Table 2 shows that during the first winter Lot I ined 58 pounds; Lot II, 79 pounds; and Lot IIl, 113 pounds. Dur$\mathrm{g}$ the following summer (Table 3), Lot I gained 127 pounds; Lot 119 pounds; and Lot III, 99 pounds per steer. 
TABLE 3.-Average Total and Daily Gain in Pounds per Steer on Pasti During the Three Summer Periods.

\begin{tabular}{|c|c|c|c|c|c|}
\hline $\begin{array}{c}\text { Years and Days on } \\
\text { Pasture }\end{array}$ & Lots & 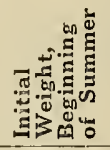 & 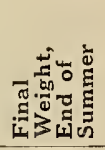 & 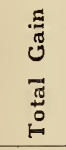 & $\begin{array}{l}. \pi \\
0 \\
0 \\
\pi \\
0\end{array}$ \\
\hline $\begin{array}{l}1923 \text { (236 days) } \\
1924 \text { (241 days) } \\
1925 \text { (141 days) }\end{array}$ & 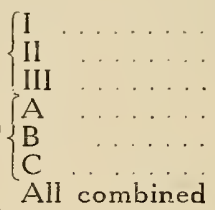 & $\begin{array}{l}446 \\
462 \\
502 \\
662 \\
655 \\
615 \\
940\end{array}$ & $\begin{array}{r}573 \\
581 \\
601 \\
898 \\
916 \\
900 \\
1,259\end{array}$ & $\begin{array}{r}127 \\
119 \\
99 \\
236 \\
261 \\
285 \\
319\end{array}$ & $\begin{array}{l}1 . \\
1 . \\
2 .\end{array}$ \\
\hline
\end{tabular}

During the second winter Lot $A$ gained 87 pounds; Lot $B$, pounds; and Lot C, 40 pounds. In the second summer Lot $A$ gain 236 pounds; Lot B, 261 pounds; and Lot C, 285 pounds.

These data show that when the cattle are turned on grass in $t$ summer (without additional feed) the lots which gain heavily duri the previous winter do not gain so much in the following summer, a: that the lots gaining least in winter make relatively large summ gains.

\section{COMPARISONS OF WINTER RATIONS}

In order to make a more complete study of the effect of differe winter rations from year to year on the grass-fat steers ultimately $\mathrm{pr}$ duced, Table 4 was prepared.

Since all 90 head were fed the same ration during the thi winter, as noted before, Table 5 comparing the first two years is give

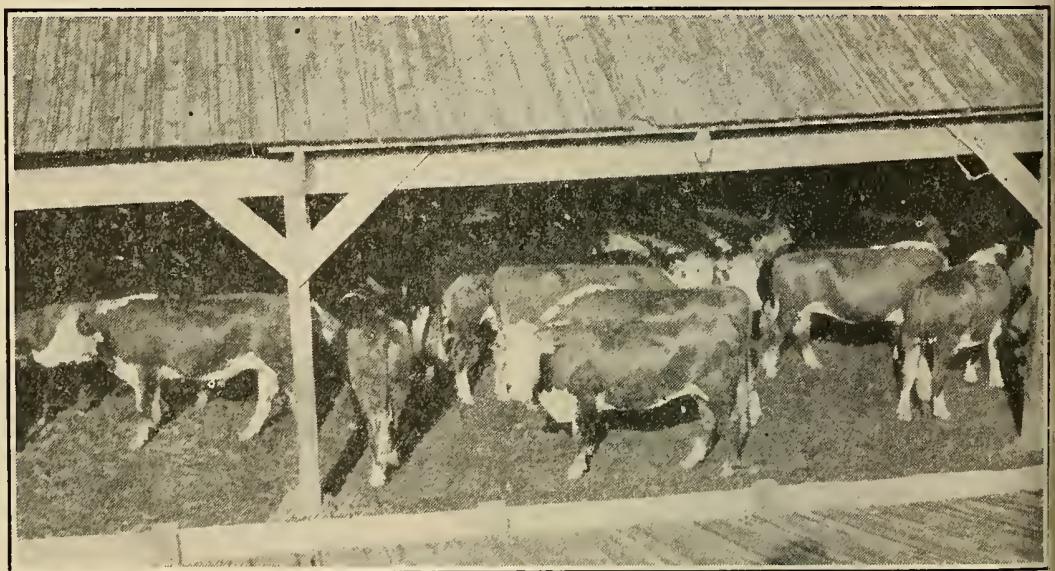

Fig. 3.-Three-year-old Steers at Close of Experiment, on Arrival at Jersey City Mar September, 1925. 
1.BLE 4.-Average Weights of Steers at Beginning and End of Each Winter Period in Pounds.

Lots and Rations

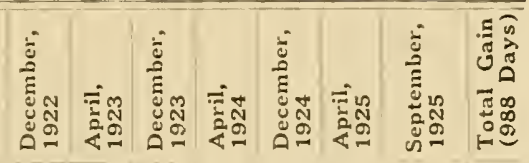

10 steers from Lot I, fed clover hay. ilage, and straw first winter

10 steers from Lot II, fed cottonseed neal, silage, and straw first winter

10 steers from Lot III, fed mixed hay and grain mixture first winter

Lats $A_{1,2,3}$ fed clover hay, silage, and straw second winter

10 steers from Lot $I$ fed as $A_{1}$

10 steers from Lot II, fed as $A_{2}$

10 steers from Lot 111 , fed as $A_{3}$

Lots $B_{1,2,3}$ fed cottonseed meal, silage, and straw second winter

10 steers from Lot 1 fed as $A_{1}$

10 steers from Lot II fed as $A_{2}$.

10 steers from Lot 111 fed as $A_{3}$.

Lots $\mathrm{C}_{1,2,3}$ fed mixed hay, corn silage, and wheat straw second winter

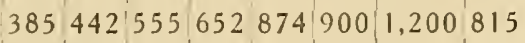

$371 \mid 4475626358799191,213842$

$398515609698940969: 1,302904$

$374432542615858902 \quad 1,202828$

$391476 \quad 589680947999 \quad 1,268: 877$

$379488599671942 \mid 96511,291912$

$404465592632927960 \quad 1,307903$

\begin{tabular}{ll|l|l|l|l|l|l|l|l|l|l|l|}
387 & 463 & 561 & 607 & 886 & 933 & 1,284 & 897
\end{tabular}

$390502572\left|608^{\prime} 891919\right| 1,259869$

\section{COST OF RATION}

To figure the cost of wintering and summering the steers (Table it becomes necessary to fix the prices for feeds used in the experiient. On account of fluctuations of the market, and also for simicity in making the various calculations, an approximation of the lial market feed prices per ton and pasture per day for the three ars was used as follows:

( $\mathrm{rn}$ silage $\$ 6.00$

(ttonseed meal 50.00

ixed hay

18.00

over hay

17.00

reat straw 7.00

(ain mixture*

Isture per day:

Yearlings 39.76

2 -year-olds

3 -year-olds

The cost of the winter feed was considerably more than the cost summer feed, yet the gain was made chiefly in summer.

\section{ANALYSES OF FEEDS}

The feeds used during the winter feeding in these experiments "ere analyzed by the West Virginia Agricultural Experiment Station. re analyses are shown in Table 7.

*Based on corn at 96 cents a bushel, wheat bran at $\$ 40$ a ton, and linseed meal at a ton. 
TABLE 5.-Comparison of Winter and Summer Gains, in Pounds, First $T$, Years of Experiment.

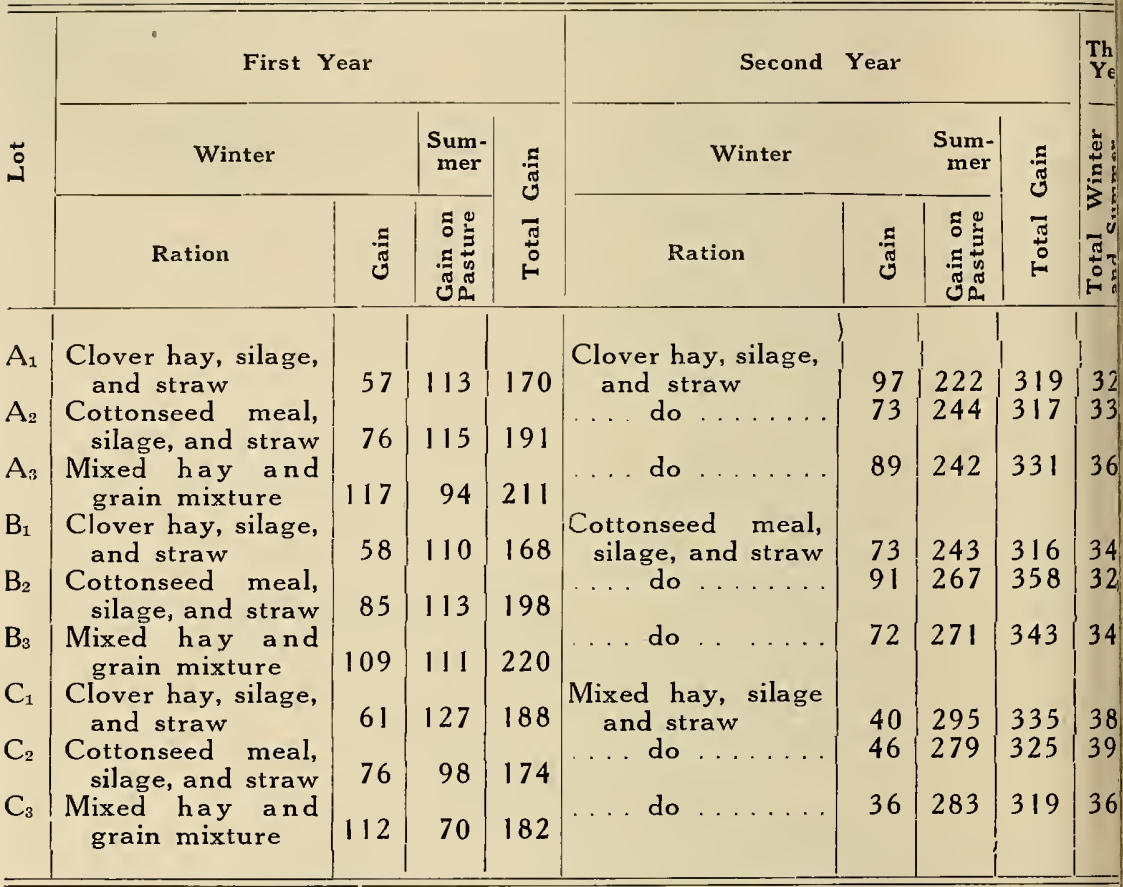

Groups $A_{1}, B_{1}$, and $C_{1}$ were fed as Lot 1 the first winter.

Groups $A_{2}, B_{2}$, and $C_{2}$ were fed as Lot 11 the first winter.

Groups $A_{3}, B_{3}$, and $C_{3}$ were fed as Lot 111 the first winter. groups Lot III.

During the second winter all A groups constituted Lot I, B groups Lot II, and

TABLE 6. - Cost per Steer of Winter Feed and Summer Pasture, and Cost pe Pound of Total Gain.

\begin{tabular}{|c|c|c|c|c|c|c|c|c|c|c|}
\hline & \multirow{2}{*}{ Lots } & \multirow{2}{*}{ 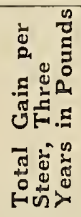 } & \multicolumn{7}{|c|}{ Cost of Feed per Steer } & \multirow{2}{*}{ 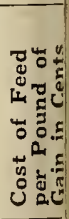 } \\
\hline & & & 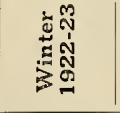 & 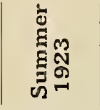 & 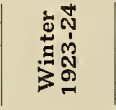 & 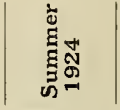 & 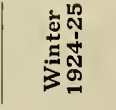 & 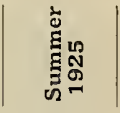 & : & \\
\hline $\begin{array}{l}\mathrm{A}_{1} \\
\mathrm{~A}_{2} \\
\mathrm{~A}_{3} \\
\mathrm{~B}_{1} \\
\mathrm{~B}_{2} \\
\mathrm{~B}_{3} \\
\mathrm{C}_{1} \\
\mathrm{C}_{2} \\
\mathrm{C}_{3}\end{array}$ & $\cdots$ & $\begin{array}{l}815 \\
842 \\
904 \\
828 \\
877 \\
912 \\
903 \\
897 \\
869\end{array}$ & $\begin{array}{r}\$ 8.42 \\
8.34 \\
18.49 \\
8.42 \\
8.34 \\
18.49 \\
8.42 \\
8.34 \\
18.49\end{array}$ & $\begin{array}{r}\$ 7.08 \\
7.08 \\
7.08 \\
7.08 \\
7.08 \\
7.08 \\
7.08 \\
7.08 \\
7.08\end{array}$ & $\begin{array}{r}\$ 12.48 \\
12.48 \\
12.48 \\
11.61 \\
11.61 \\
11.61 \\
12.78 \\
12.78 \\
12.78\end{array}$ & $\begin{array}{r}\$ 12.05 \\
12.05 \\
12.05 \\
12.05 \\
12.05 \\
12.05 \\
12.05 \\
12.05 \\
12.05\end{array}$ & $\begin{array}{r}\$ 15.33 \\
15.33 \\
15.33 \\
15.33 \\
15.33 \\
15.33 \\
15.33 \\
15.33 \\
15.33\end{array}$ & $\begin{array}{r}\$ 14.10 \\
14.10 \\
14.10 \\
14.10 \\
14.10 \\
14.10 \\
14.10 \\
14.10 \\
14.10\end{array}$ & $\begin{array}{r}\$ 69.46 \\
69.38 \\
79.53 \\
68.59 \\
68.51 \\
78.66 \\
69.76 \\
69.68 \\
79.83\end{array}$ & \begin{tabular}{l|}
8.5 \\
8.2 \\
8.8 \\
8.3 \\
7.8 \\
8.6 \\
7.7 \\
7.8 \\
9.2
\end{tabular} \\
\hline
\end{tabular}


ABLE 7.-Analyses of Feeds, Reported in Percentages.

\begin{tabular}{|c|c|c|c|c|c|c|c|}
\hline Feed & Year & Water & Ash & Protein & Fiber & $\begin{array}{c}\text { Nitro- } \\
\text { gen-Free } \\
\text { Extract }\end{array}$ & Fat \\
\hline $\begin{array}{l}\text { lage } \ldots \ldots \\
\text { over hay } \ldots \ldots \\
\text { ixed hay } \ldots \ldots \\
\text { heat straw } \ldots \\
\text { srn } \ldots \ldots \ldots \\
\text { nseed meal } \\
\text { stonseed meal }\end{array}$ & $\begin{array}{l}1922-23 \\
1923-24 \\
1922-23 \\
1923-24 \\
1922-23 \\
1923-24 \\
1922-23 \\
1923-24 \\
1922-23 \\
1922-23 \\
1922-23 \\
1923-24 \\
1922-23\end{array}$ & $\begin{array}{r}64.07 \\
60.50 \\
5.60 \\
6.34 \\
5.90 \\
5.10 \\
4.87 \\
5.08 \\
8.60 \\
7.93 \\
8.44 \\
8.14 \\
7.91\end{array}$ & $\begin{array}{l}1.06 \\
3.15 \\
4.77 \\
5.20 \\
4.96 \\
4.04 \\
4.03 \\
3.49 \\
1.23 \\
4.86 \\
5.94 \\
6.56 \\
6.60\end{array}$ & $\begin{array}{r}2.64 \\
3.06 \\
8.81 \\
9.61 \\
8.64 \\
6.14 \\
4.48 \\
4.08 \\
9.98 \\
35.76 \\
34.28 \\
36.46 \\
15.76\end{array}$ & $\begin{array}{r}5.92 \\
7.43 \\
40.70 \\
34.14 \\
35.54 \\
31.51 \\
41.66 \\
42.27 \\
2.58 \\
8.22 \\
12.95 \\
11.42 \\
10.61\end{array}$ & $\begin{array}{l}24.87 \\
24.37 \\
38.32 \\
42.55 \\
42.75 \\
50.58 \\
43.68 \\
43.44 \\
73.20 \\
36.11 \\
32.02 \\
30.78 \\
53.64\end{array}$ & $\begin{array}{l}1.44 \\
1.49 \\
1.80 \\
2.16 \\
2.21 \\
2.63 \\
1.28 \\
1.64 \\
4.41 \\
7.12 \\
6.37 \\
6.64 \\
5.48\end{array}$ \\
\hline
\end{tabular}

\section{CONCLUSIONS}

From a study of the growth curves shown in Figures 4 and 5 it ay be seen that a loss in weight during the last two months of the azing periods occurred both in 1923 and 1924. In other words, e average weight of the 90 steers on October 10, 1923, was practicly the same as it was six months later, or April 18, 1924. This ggests a point worthy of more study and investigation. This loss weight after frost comes in the fall and before putting the cattle to winter quarters should undoubtedly be avoided. The solution ay lie either in supplementing this late fall pasture with grain or in acing the cattle into winter quarters earlier.

As a rule the lots of calves and yearlings which made the least inter gains made the greatest summer gains, and conversely the lots ining most in winter gained least in summer on pasture.

Differences in gains made by calves and yearlings during the nters, 1922-23 and 1923-24 brought about by the rations fed were inimized during the summers of 1923 and 1924 when they were on isture.

There were relatively little differences between the average anal gains of the different lots of calves and yearlings at the end of the st and second summer grazing periods. When these lots of calves $d$ yearlings were then fed the same winter ration as two-year-old : ers and finished on pasture as three-year-old steers all lots sold in rsey City at the same price per pound. Therefore, the cost of winring rations, fed in this experiment, is of relatively greater importce than the kind of ration when fed to calves and yearlings that are be finished on pasture as three-year-old steers. 


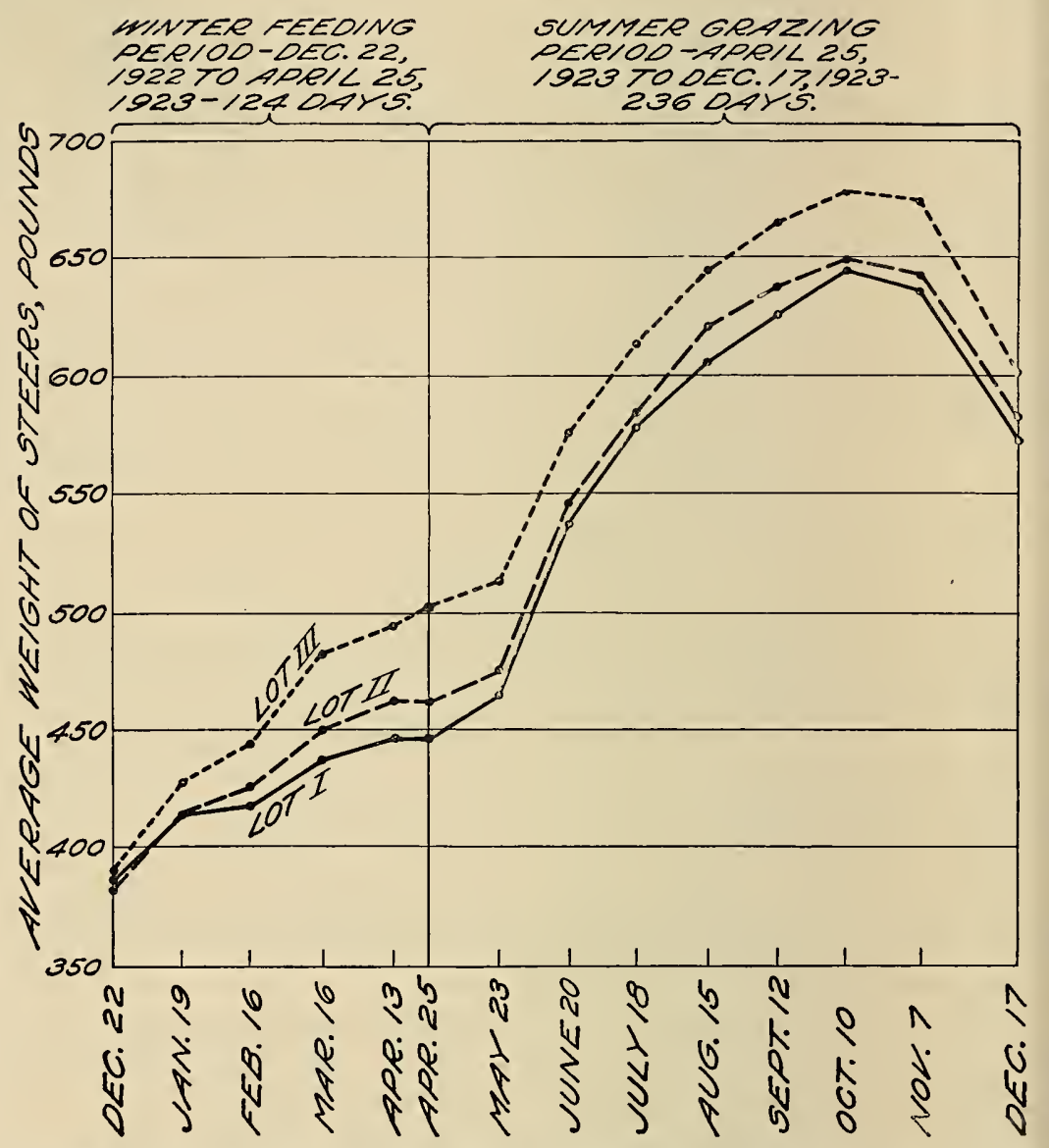

Fig. 4.-Gains of Steers During Winter and Summer, December 22, 1922, to Deceml $17,1923$. 


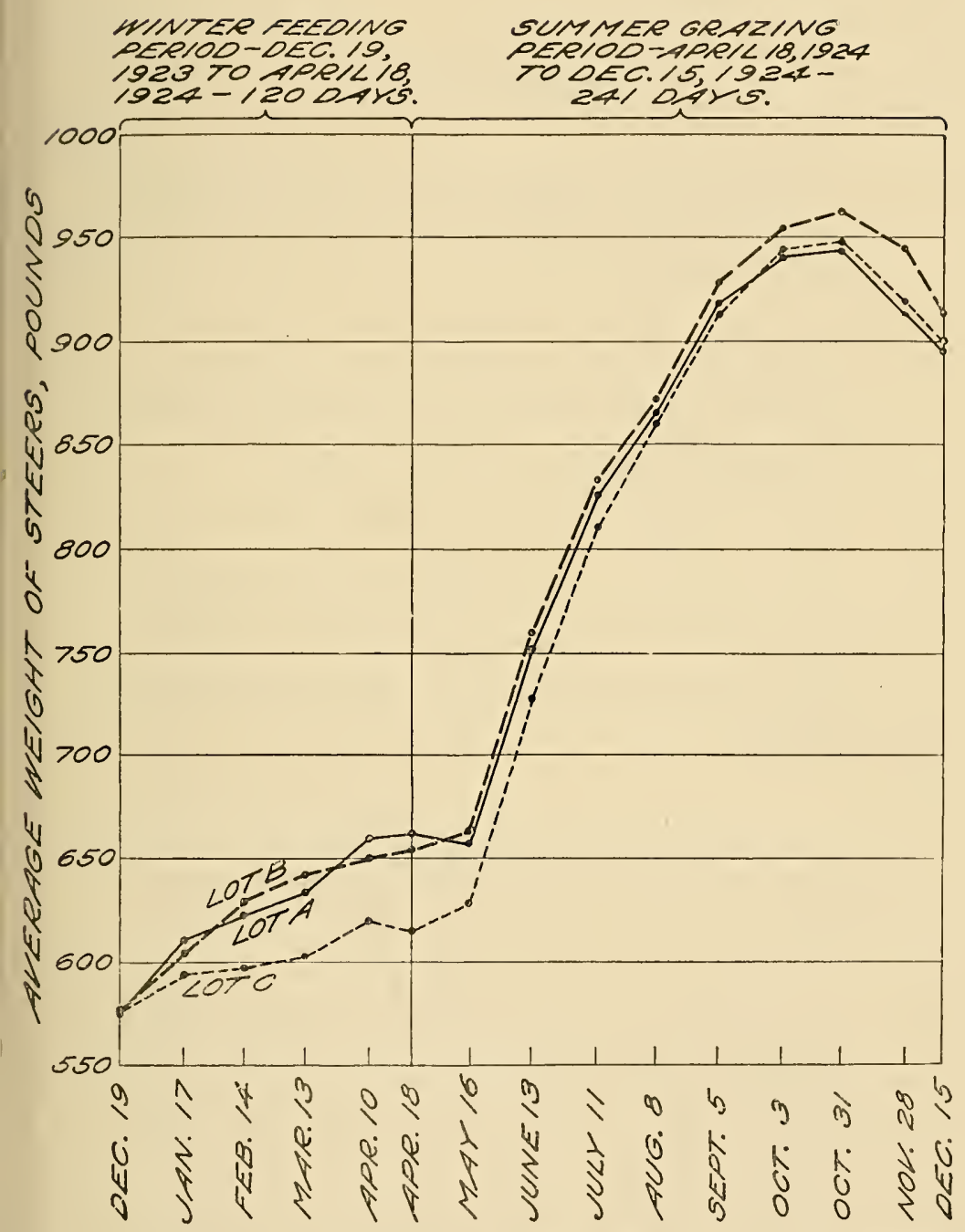

3. 5.-Gains of Steers During Winter and Summer, December 19, 1923, to December 15, 1924. 


\section{FERRETED FACTS}

Fourteen years (1914-28) of experimental investigations as to feeding of beef cattle on the Tuckwiller Farm show conclusively:

1. - That the cost of winter feeding is the most important factor in the economy of beef production for the area represented by this work. (See Figure 1.)

2. - That the use of corn silage will lower the cost of winter feeding and when fed along with the ordinary farm roughages will enable the farmer to feed more cattle for a longer period than he can on the same feed if fed in a dry state alone.

3. - That corn silage with a good leguminous roughage makes a satisfactory and economical wintering ration for cattle of any age including breeding cows.

4. - That winter gains exceeding 75 pounds on threeyear-old steers are excessive unless the cattle are extremely thin when placed in winter quarters, or it is desired to market them as early as July. 


\section{You Are Invited}

Farmers who live in the Greenbrier Valley section or whose business or pleasure brings them within proximity of Lewisburg are cordially invited to visit the Tuchwiller Farm and see at first hand. the cooperative experimental work that is being conducted there with beef cattle.

A three-year experiment with three-year-old stecr's has just been completed, in which two grades of steers, good and medium, were compared, and grass alone for summer feeding contrasted with grass supplemented by grain. Results of this work are being prepared and will be published at an early date.

Starting in the fall of 1928 further work with grain feeding will be continued for a three-year period. Younger cattle will be used and a study of the time at which to begin grain feeding on grass will be made.

The Tuckwiller Farm is readily accessible at all seasons of the year being located on the Midland Trail 4 miles west of Lewisburg and 106 miles east of Charleston. It is suggested that a visit to the farm would make a good tour or vacation trip for a group of farmers who might arrange to make the trip together. Any group desiring to visit the farms and see this experimental work may obtain information as to the times at which winter feeding will begin and end, summer feeding begin, and final summer weights be taken, by writing to the Animal Husbandry Department of the West Virginia Agricultural Experiment Station at Morgantown. 


\section{Beef Cattle In West Virginia}

The raising of beef cattle has a very definite place on many W' est Virginia farms as an important farm enterprise. The profitableness of the enterprise, however, depends upon how well the farmer understands the fundamental principles of feeding, care, and management and is able to apply them.

The West Virginia College of Agriculture is striving through the work on its Experiment Station to discover facts about the raising of beef cattle that will be of help to the farmers in the state in making the enterprise more successful and profitable.

These facts are disseminated in three major ways: (1) By the teaching staff of the College through resident instruction to students; (2) Through the work of Extension Division and its field representatives-the livestock specialists and county agricultural agents; and (3) Through the means of publications which are distributed free to those interested.

If you have any special problems, in handling your beef cattle, consult your county agricultural agent, or write to the College for suggestions and aid. One of the following publications of the Experiment Station may contain the information you need:

Bul. 186, Effect of Winter Rations on Pasture Gains of Beef Calves and Yearlings.

Bul. 190, Feeding Experiments With Grade Beef Cows.

Bul. 191, Effect of Winter Rations on Pasture Gains of Two-Year-Old Steers.

Cir. 40, A brief extract of bulletin 191 (8 pages).

Bulletins and circulars on other farm problems are also available for distribution. A complete list of available publications will be issued about January 1, 1929. Write for it. Address your request to

\section{COLLEGE OF AGRICULTURE}

West Virginia University

Morgantown, W. Va. 




\section{HECKMAN}

BINDERY INC.

\section{JUNE 99}

Bound -To-Pleas N. MANCHESTER INDIANA 46962 
Sit. 